\title{
ABNORMAL REACTION TO PROCAINE AND SUCCINYLCHOLINE IN A PATIENT WITH INHERITED ATYPICAL PLASMA CHOLINESTERASE: CASE REPORT
}

\author{
Elemér K. Zsigmond, M.D., AND Thomas E. Eilderton, D.D.s.*
}

THE HYDROLYSIS of procaine hydrochloride and structurally related ester-type local anaesthetics by plasma cholinesterase was systematically studied by Kalow and associates. ${ }^{1}$ Subsequently, Kalow and Genest ${ }^{2}$ reported the existence of an atypical plasma cholinesterase. An atypical homozygous enzyme was present in about 0.03 per cent of the population and was correlated with the development of prolonged apnoea following the use of succinylcholine. ${ }^{3-5}$ It was also shown that the hydrolysis rate of procaine and ester-type local anaesthetics was reduced in patients possessing atypical homozygous plasma cholinesterase. Consequently, it was assumed that the use of large amounts of ester-type local anaesthetics may result in severe systemic reactions in patients with atypical plasma cholinesterase.

\section{CASE Report}

A 29-year-old female was referred to our laboratory for the determination of plasma cholinesterase activity. This patient presented a history of an episode of prolonged apnoea lasting two hours following the administration of succinylcholine for relaxation during abdominal surgery. One week following the apnoeic episode, the plasma cholinesterase activity of the patient was determined. The results presented in Table I show that the patient was an atypical homozygote, since the D.N. was 18 . Several months later the patient had an uneventful delivery under spinal anaesthesia.

Seven years prior to her abdominal surgery, the patient had undergone dental extractions. A few minutes after the injection of procaine, she had become weak, felt nauseated and dyspnoeic, and become cyanotic and unconscious from hypoxia. The patient was successfully resuscitated with oxygen and vasopressors.

After our tests were made on the patient, the plasma cholinesterase activity and dibucaine number of her four available relatives were also determined. The values are presented in Table I. It is evident that three of the relatives were heterozygotes of the normal and atypical genes for plasma cholinesterase and one relative was a normal homozygote. The sister of the patient (G.C.) developed cardiovascular collapse after the administration of 16 c.c. of 2 per cent procaine for pudendal nerve block anaesthesia and was resuscitated successfully. The three other relatives studied had no prior surgery requiring succinylcholine, but had dental extraction with local anaesthetic of an unknown type.

'Dr. Zsigmond is Director, Anesthesia Research Laboratory, Allegheny General Hospital, Pittsburgh, Pennsylvania. Dr. Eilderton is Oral Surgeon, Sewickley Valley Hospital, Sewickley, Pennsylvania. Reprint requests should be sent to Dr. Zsigmond. 
TABLE I

Plasma Cholinesterase Activity and Dibucaine Numbers of the Patient and Her Relatives

\begin{tabular}{|c|c|c|c|c|c|}
\hline \multirow[b]{2}{*}{ Initials } & \multirow[b]{2}{*}{ Relationship } & \multicolumn{2}{|c|}{ Hydrolysis rates* } & \multirow[b]{2}{*}{ D.N. $\dagger$} & \multirow{2}{*}{$\begin{array}{c}\text { Toxic reaction } \\
\text { to procaine }\end{array}$} \\
\hline & & Benzoylcholine & Procaine & & \\
\hline $\begin{array}{l}\text { A.W. } \\
\text { W.W. } \\
\text { G.W. } \\
\text { J.W. } \\
\text { G.C. }\end{array}$ & $\begin{array}{l}\text { patient } \\
\text { sister } \\
\text { daughter of W.W. } \\
\text { son of } W . W . \\
\text { sister }\end{array}$ & $\begin{array}{l}\mathbf{1 5 . 6} \\
\mathbf{1 7 . 8} \\
58.8 \\
40.6 \\
31.6\end{array}$ & $\begin{array}{c}0.270 \\
1 . \overline{256} \\
1.178 \\
0.300\end{array}$ & $\begin{array}{l}18 \\
35 \\
74 \\
54 \\
47\end{array}$ & $\begin{array}{l}\text { yes } \\
\text { no } \\
\text { no } \\
\text { no } \\
\text { yes }\end{array}$ \\
\hline \multicolumn{2}{|c|}{$\begin{array}{l}\text { Normal values for males } \\
\text { Normal values for females }\end{array}$} & $\begin{array}{r}104.5 \pm 29.6 \ddagger \\
81.4 \pm 27.4 \ddagger\end{array}$ & $\begin{array}{l}1.12 \pm 0.23 \ddagger \\
1.09 \pm 0.34 \ddagger\end{array}$ & $\begin{array}{l}70-80 \\
70-80\end{array}$ & - \\
\hline
\end{tabular}

*Hydrolysis rate is expressed in $\mu$ moles hydrolysed by $1 \mathrm{ml}$. plasma in one hour.

†D.N. $<20$-atypical homozygote.

D.N. $=20-70-$ atypical-normal heterozygote.

D.N. $>70$-normal homozygote.

Classifications of Kalow and Genest (1957).

†Standard deviation.

\section{Discussion}

This case report corroborates the previous findings of Foldes et al. ${ }^{5}$ that individuals possessing atypical plasma cholinesterase may develop systemic reactions to ester-type local anaesthetics. Although the development of prolonged apnoea following the administration of succinylcholine in patients with atypical cholinesterase is known, no case has been reported of the occurrence of both complications in the same patient. Our case report calls attention to this correlation. Therefore, the plasma cholinesterase activity and dibucaine number of the patients and their families who develop either prolonged apnoea following the use of succinylcholine or toxic reaction to the ester-type local anaesthetics must be studied to prevent future complications and fatalities.

\section{SUMMARY}

Prolonged postoperative apnoea has been reported to occur frequently after the intravenous injection of succinylcholine in patients possessing atypical plasma cholinesterase. Reduced hydrolysis rates of ester-type local anaesthetics were also found to be associated with this condition. This is the first documented case in which the same patient developed prolonged apnoea after the use of succinylcholine and peripheral cardiovascular collapse after the use of procaine for dental surgery on two other occasions. Determination of plasma cholinesterase activity and the dibucaine number revealed that the patient possessed an atypical homozygous plasma cholinesterase. Of the available four relatives of the patient, three proved to be atypical-normal heterozygotes and one a normal homozygote. One of the relatives, a heterozygote, developed severe systemic toxic reactions after the administration of procaine for pudendal nerve block. The presence of atypical plasma cholinesterase may explain some of the unclarified "anaphylactic" reactions to local anaesthetics in patients. 


\section{RÉSUMÉ}

On a rapporté qu'une apnée post-opératoire prolongée se produit fréquemment chez des malades à cholinestérase atypique, après injection intraveineuse de succinylcholine. On a trouvé aussi que des taux réduits d'hydrolyse des anesthésiques locaux de type ester sont associés à cette condition. Ceci est le premier dossier complet rapportant que le même malade a eu une apnée prolongée après l'administration de succinylcholine et a souffert à deux reprises d'une défaillance cardiovasculaire périphérique après avoir reçu de la procaïne pour subir des extractions dentaires. La détermination de l'activité de la cholinestérase du plasma et le "dibucaïne number" ont révélé que le sujet était porteur de cholinestérase plasmatique atypique homozygote. Des quatre parents de ce malade que nous avons pu retracer, trois se sont avérés des hétérozygotes atypiques normaux. L'un deux, hétérozygote, a présenté de sévères réactions toxiques générales après avoir subi un bloc honteux à la procaïne. La présence de cholinestérase plasmatique atypique peut expliquer quelques unes des réactions "anaphylactiques" obscures consécutives à des anesthésies locales.

\section{REFERENCES}

1. Kalow, W. Hydrolysis of Local Anesthetics by Human Serum Cholinesterase. J. Pharmacol. Exper. Therap. 104: 122 (1952).

2. Kalow, W. \& Genest, K. A Method for the Detection of Atypical Forms of Human Serum Cholinesterase. Determination of Dibucaine Numbers. Canad. J. Biochem. 35: 339 (1957).

3. Davies, R. O.; Morton, A. V.; \& Kalow, W. The Action of Normal and Atypical Cholinesterase of the Human Plasma upon a Series of Esters of Choline. Canad. J. Biochem. 38: 545 (1960).

4. Kalow, W. \& Staron, N. On Distribution and Inheritance of Atypical Forms of Human Serum Cholinesterase as Indicated by Dibucaine Numbers. Canad. J. Biochem. 35: 1305 ( 1957 ).

5. Foldes, F. F.; Foldes, V. M.; SMIth, J. C.; \& Zsigmond, E. K. The Relation between Plasma Cholinesterase and Prolonged Apnea Caused by Succinylcholine. Anesthesiology. 24: 208 (1963). 